

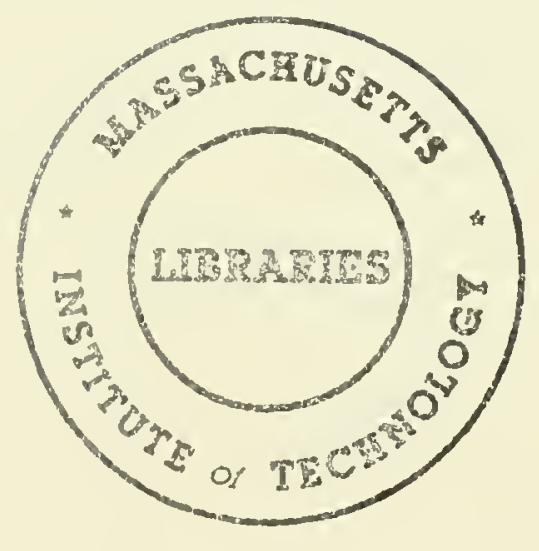






\section{WORKING PAPER \\ ALFRED P. SLOAN SCHOOL OF MANAGEMENT}

THE NEW KEYNESIAN MICROFOUNDATIONS

Julio Rotemberg

Working Paper \#1925-87

August 1987

\section{MASSACHUSETTS}

INSTITUTE OF TECHNOLOGY

50 MEMORIAL DRIVE

CAMBRIDGE, MASSACHUSETTS 02139 
<smiles>CCCCCCC</smiles> 
THE NEW KEYNESIAN MICROFOUNDATIONS

\title{
Julio Rotemberg
}

\author{
Working Paper \#1925-87
}

August 1987 

The New Keynesian Microfoundations

Julio Rotemberg Revised April 1987

Sloan School of Management and NBER. I would like to thank Olivier Blanchard, Stephen Cecchetti, Stanley Fischer, Greg Mankiw, Caterina Nelson and Lawrence Summers for helpful comments and suggestions. Stephen Cecchetti also made his data avallable. 


\section{THE NEW KEYNESIAN MICROFOUNDATIONS}

\section{Abstract}

This paper surveys some recent efforts at deriving the standard Keynesian effects of money on output from modeis in which individual agents maximize their weifare. While other modeis with continua of equilibria are considered, most attention is spent on model with costs of changing prices. Models of the latter type also turn out to have multiple equilibria because, when a firm increases its price, Its creates an incentive for its competitors to raise their own. These multiplicitles are discussed in both two period and infinite horizon models. The multiplicities affect both the qualitative features of the equilibria and their welfare properties. I also analyze the extent to which small costs of changing prices can generate large (or costiy from a welfare viewpoint) business cycles. Aggregate data and data on individual prices is used to discuss the empirical strengths and weaknesses of existing models. 



\section{Introduction}

The central idea of Keynesian economics is that increases in demand stimulate aggregate actlvity. The contrast wlth classical models is clearest when an increase in the money suppiy is considered. In ciassical modeis with textbook-style demand curves for money baiances, an unexpected once and for all increase in the money simply raises all nominal prices ${ }^{1}$. According to Keynes and his followers prices (or wages) respond slowly and the resulting increase in real money baiances raises output. ${ }^{2}$

This paper surveys some recent efforts at deriving this effect of money on output using models in which individual agents maximize their welfare.

The models provide microfoundations in that they start from these optimizing agents and construct equillbria in which no individual agent wants to change what she is doing. Two types of models are considered. The first assumes explicitly or implicitly that, for each individuai firm, there is some cost of changing its price. This assumption, which may appear somewhat ad hoc, has the advantage of belng consistent with the rather long spells for which individuai prices remain constant. In the second category are models with continua of equilibria. In these models, money affects output by moving the economy from one equilibrium to another. Whlle the pressure for output to return to its normal level is weak in the first category of models it is nonexistent in the second. The two types of modeis also share another characteristic. Several of the multiple equllibrium modeis lay considerable stress on departures from the Wairasian model which are aiso important in the literature on costly price adjustment.

I am thus surveying here only a subset of the models whose authors have 
adopted the "Keynesian" label. Because of space considerations, I only include models in which output depends on nominal variables such as money. These provide the starkest contrast with classical models. It is worth mentioning however that the label "Keynesian" has been affixed also to models in which preexisting distortions magnify the effect of government spending on output $^{3}$. The mechanisms incorporated in those models may well also magnify the effects of money on output considered here.

While my emphasis is on models in which there is an effect of money on output, it is worth emphasizing that, if price are rigid, other variables are important as well. In particular, with rigid prices falls in Investment demand (due to animal splrits or pessimism about the future) are not accomodated by falls in the prlces of these goods. Instead, they directly reduce the output of these sectors and aggregate output. Similar reasoning applies to changes in government spending.

The prototype model of the first type whlch I consider devlates from the Walrasian paradigm in three ways. First, certain agents set prices. This is necessary for it is hard to think of a Walrasian auctioneer, whatever that is, which keeps prices rigid. Usually the agents that set prices are viewed as monopolistic competitors.

Second, since the emphasis is on nominal rlgidities some nominal varlable must matter. This is accomplished by postulating a textbook-style demand for money. When only these two devlations are operative, unanticipated, once and for all increases in nominal aggregate demand, which are usually modelled as increases in money do not affect the real allocation of resources. The third and critical ingredient in the prototype model is some reason for prices to be rigld. In Barro (1972), Sheshinski and Weiss (1977), Rotemberg (1982a,b,1983), Mankiw (1985), Parkin (1986) and Ball and 
Romer (1986b) there exists an explicit cost of changing prices while Blanchard $(1983,1985)$, Akerlof and Yellen (1985), Calvo (1983), Caplin and Spuiber (1986) and Ball and Romer (1986a) restrict directly the frequency of price adjustment.

Given thls list of ingredients, one might ask in all seriousness what is new about the current generation of Keynesian models. The major difference between the current and previous generations (Fischer (1976), Tayior (1980a)) is an emphasis on the behavior of product markets ${ }^{4}$. This emphasis has one important theoretical advantage. This advantage is that it is possible to be quite precise about what a monopolistic seller of a good would do if, say, prices are costiy to change. This is in contrast of standard models of wage rigidity. In those models it is difficult to model simultaneously the presence of wage rlgidity and the behavior of firms and workers in the presence of the rigidity. In particular, it is hard to see why, if wages are truly rigld, firms are able to hire as much labor as they desire at the rigid wages.

This theoretical advantage also has an empirical counterpart. As Barro (1977) and Hall (1980) have pointed out the observation of infrequent changes in indlviduals' wages does not prove the existence of allocative consequences from wage rigidity. The reason for this is that rigid individual wages are at least consistent with efficient determination of the level of employment. As discussed in Section II, it is much more difficult to argue that the observed rigidity of consumer goods prices has no effect on resource allocation. In that Section I, also discuss aggregate evidence for the existence of price rigiditles.

A second advantage that is sometimes claimed for the new Keynesian models is that they require only small price rigidities to produce large 
fluctuations in GNP. This point is due to Akerlof and Yellen (1985), Mankiw (1985) and Parkin (1986) and will be referred to as the PAYM insight. The insight is that the profit function of any agent who sets prices is horizontal at that agent's optimum price. Hence small deviations from the optimal price lead to only second order losses. Yet they are consistent with large output swings. In Section III, I discuss somewhat more generally the applications of this insight to macroeconomic problems.

The paper then goes on to present in Section IV a static model of monopolistic competition which forms the basis for the later discussion of price rigidity. This model is classical in that, without price rigidities, its unique equilibrium has monetary shocks affecting prices alone. In Section V, a once and for all change in the money stock is analyzed in a simple two period variant of the static model to which costs of changing prices have been added. In this model monetary expansions, at least if they fall within a certain range, affect output. While some issues which arlse in models with more periods are masked by the two period assumption, this model has several interesting features including a multiplicity of equilibria. In particular, for a range of monetary shocks both changed and unchanged prices can be consistent with equilibrium.

The welfare properties of equilibrium price rigidity in response to monetary shocks is explored in Section VI. The question which is addressed also in Ball and Romer (1986b, 1987) is, granted that changing prices is costly, do prices respond too much or too little to monetary shocks. These welfare conclusions prove to be ambiguous precisely because of the multiplicity of equilibria. This multiplicity is also one reason for the apparent difficulty inherent in anaylizing the models with infinite horizons and multiple periods. These are covered in Section VII. 
Section VIII focuses on models in which the multiplicity of equilibria is, by itself, taken to be Keynesian. Here, the different equilibria can be thought of as being due to differences in the beilefs individuais can have about the future or about the current behavior of others. Since the equilibrium that is chosen is a function of expectations, these equilibria can be though as depending on animal spirits.

In these models, which include Stiglltz $(1979,1984,1985)$, Diamond (1982), Weitzman (1982), Woglom (1982), Bryant (1983), Geanakoplos and Polemacharkis (1986), Roberts (1986) and Woodford (1986), money affects economlc activity if it switches the economy from one equllibrium to another. Some of these models exhibit recognizable price rigidity while other do not. In any event they all avoid any explicit cost of changing prices. An issue which is more important here than in the discussion of the models of the first type is why the particular Keynesian sequence of equilibria is chosen. Section VI concludes with my personal assessment of the new Keynesian microfoundations and of promising directions of future research.

\section{The factual background}

The most discussed evidence for the existence of nominal rigidities of any kind is the correlation of current GNP with past values of the money supply. Since the work of Sims (1972), this correlation has been studied in the context of relatively unconstrained vector autoregressions. The hypothesis that this correlation is absent from US data (or that money fails to Granger cause output) can be rejected using some specifications while it can be accepted using others. Eichenbaum and Singleton (1986) and Bernanke (1986) are two recent examples of opposite results. 
Leaving aside statistical significance, if increases in money are correlated with subsequent increases in output because of nominal rigidities they should also be correlated with gradual increases in prices. It is in fact the slow response of prices which is at the center of the much more structured empirical analysis of Rotemberg (1982a) as well as of the evidence on nominal rigidities presented in Gordon (1983). I thus report on the responses of the price level and output to a monetary innovation within a vector autoregression very similar to Bernanke (1986)'s. The vector of variables that I consider consists of the logarithms of mllitary spending, the money supply, GNP, the implicit price deflator for GNP, and the nominal rate of return on US treasury bllls 5 . It also includes constants and deterministic time trends. This autoregression is estimated with quarterly US data from the second quarter of 1953 to the third quarter of 1986 . Tabie 1 gives the responses of money output and prices to a one percent innovation in the money supply. As can be seen from the table output rises gradually before falling back to its long run position (this return is oscillatory) while prices rise gradually. This second fact is just as consistent with nominal rigidities as the first. Interestingly the short term dynamics do not depend very much on whether the system is estimated in first differences or not.

While the correlations between money and output have been subject to extensive empirical analysis, their interpretation is somewhat problematic because money is at least to some degree endogenous. On the one hand, King and Plosser (1983) note that the private sector may create more money when its demand is expected to rise. This suggests a positive correlation unrelated to price rigidity. On the other hand, the absence of correlation between money and ouput is consistent with nominal rigidities if the Federal 
Reserve is using money purposefully to stabilize output (See Mankiw (1986a)). Neither of these stories accounts for the gradual increase in prices which follows increases in money.

A related set of correlations which is less subject to this endogeneity is given by the relationship between tax reforms and aggregate activity. Poterba, Rotemberg and Summers (1986) note that in the absence of nominal rigidities increases in indirect taxes accompanied by reductions in direct taxes of the same magnitude should affect neither prices nor output. This can be seen as follows. Suppose the government increases sales taxes on finai goods and reduces income taxes leaving government revenue unaffected. Since the burden of taxes is the same and since these two taxes differ only by the side of the market on which money is collected, output shouid be unaffected. With an unchanged demand for money, prices should be unaffected as well. Thls means that with flexible wages and prices, pre-tax wages must fall (so that after tax nominal wages are unchanged) and pre-tax prices must fall as well (so prices inclusive of tax are unaffected). With nominal rigidities, pre-tax prices or wages will not fall thus reducing real money balances and output. Using both US and UK data, Poterba, Rotemberg and Summers find that these switches do indeed raise prices and lower output.

While this evidence supports the existence of some nominal rigidities it says little about whether wages or prices are more rigid. This extremely important question appears intrinsically difficult to answer because the ratio of wages to prices exhibits very little correlation with GNP6. This means that it appears possible to believe that only prices are subject to nominal rigidities whereas insurance or efficiency wage considerations keep real wages stable. Alternatively one may believe that only wages are subject to nominal rigidities whereas pricing is given by a constant markup over 
wages.

One notable attempt to gauge the relative rigidity of prices and wages is Blanchard (1986b). He studies how prices respond to innovations in wages and viceversa. To Identify these two innovations he restricts the contemporaneous response of each variable to the other. Under these identifying assumptions prices appear more rigid as their response to wages is slower than the response of wages to prices.

If rigidities in prices and wages are a central determinant of GNP, then, other things equal, countries with more movements in prices and wages ought to have less output fluctuations. Thus the absence of any evidence that countries with high inflation rates have more stable levels of output might be vlewed as discomfitting to nominal rigiditles. Yet, as Mankiw discusses below these countries exhibit smaller responses of output to nominal shocks. Thus the instability in their GNP is perhaps due to the existence of larger nominal disturbances.

At the micro level, it is apparent to those with eyesight that individual prices and wages stay constant for long periods of time. In the US, hourly wages are normally changed yearly even when there are no explicit contracts. The price of candy bars at the corner grocery store also changes very rarely.

The significance of the individual wage data has been widely questioned by noting that most employment relations are relatively long-term (See Barro (1977), Hall (1980)). Thus, a particular paycheck need not represent the payment for the services actually rendered the month before; it can be viewed as that month's installment on what is a rather long stream of payments. These installments could be relatively inflexible with no effect on either hours worked or even on individual consumption. For this to be true there 
must of course be some mechanism which ensures that if one worker works one additional hour today, he receives not just the current wage per hour but aiso a different amount of future payments which is appropriate given his current marginal utility of leisure.

I now turn to data on product price rigidity. The data on which Means (1935) based his assertion that prices in the US are "administered" are BLS industry price indices. These indlces move little, the index for tin remained unchanged from June 1929 to May 1937. This rigidity would be spurious if quotes given to BLS employees move less than quotes given to genuine buyers. Yet using data gathered by Stigler and Kindahl (1970) on actual transactions prices Carlton (1986) concludes that price rigidity is pervasive.

However, Carlton himself appears unsure of the allocative significance of this price rigidity. The Stigier and Kindahl data are for intermediate goods sold to firms. Many of these transactions are also part of a continuing relation. Thus they too can be viewed, at least in part, as Installment payments. In other words, there may again be mechanisms that ensure that when a firm today buys more of some good the stream of payments from the buyer to the seller is affected not only today but in the future as well. One mechanism capable of ensuring an efficient allocation which Carlton mentions is rationing, buyers may simply be unable to buy more at the posted price.

We can oniy be sure that the rigidity of a price affects resource allocation if two conditions are met. First transactions must be carried out at this price. Second there must be nothing that prevents an individuai from buying one unit more (or less) of the good and thereby having to pay only the current price for the good. Without rethinking the entire fabric of 
economics we must concede that prices of goods sold in stores to individuals fulfill both requirements.

So the evidence of Cecchetti (1986) that the newstand price of magazines is very rigid (Reader's Digest changed its newstand price six times between 1950 and 1980) is simply inconsistent with the absence of allocative effects. We can now be sure that at least some monopolistically competitive producers of goods have meaningfully rigid prices. This is one of the main advantages of focusing on such product price rigidity. Yet, once one accepts that there are some goods in which price rigidity plays some allocative role, it is difficult to maintain that the price rigidity observed in the context of more long term relationships is totally devoid of such a role.

One remarkable fact about the rigidity of individual prices is that prices of monopolies tend to stay constant for longer periods of time than do those of duopolies or uther tight ollgopolies. This fact, which has some bearing on the theories I will survey below was originally uncovered by Stigler (1947) in his attack on the kinked demand theory of oligopoly. The finding has been conflrmed by several subsequent studies. These are surveyed in Rotemberg and Saloner (1986). Unlike Reader's Digest, the newstand prices of Time and Newsweek each changed nine times between 1950 and 1980 .

\section{Objective Functions are Flat at the Top}

In this Section I discuss somewhat broadly the advantage conferred on Keynesian economics of the PAYM insight that price setters have only second order costs of being away from their optimal price. Taken as a broad statement about the fact that small deviations from optimal actions can have macroeconomic consequences it offers a great many possibilities. 
For instance, consider a Robinson Crusoe economy in which Crusoe must work to eat. There is an optimal amount of work that solves the food-leisure choice of Crusoe. Yet, at this optimum point, Crusoe is strictiy indifferent between working and not working a little bit more. Small changes in work have only a second order effect on utility.

Now suppose we follow Akeriof and Yellen (1985) and consider "nearrational" strategles. These strategles are defined as leading to at most second order losses reiative to rational strategles. A straightforward nearrationai model of macro fluctuations would have Robinson Crusoe simply randomize a little bit over the amount of effort he expends ${ }^{7}$. Such a model would have the considerable advantage of simplicity. This model could also explain the comovements of other variables with GNP; nothing prevents Crusoe's randomization from being a little bit systematic. 8

One objection to this use of PAYM insight is that in the Crusoe model the welfare cost of the economic fluctuations is of second arder. Instead, it might be argued that in the presence of monopoly or other distortion, the costs to the individual who leaves his prlce unchanged can be of second order while, simultaneously, the cost to society from the price rigidity may be of first order. Below I quarrel with this vlew; it appears invalid whenever output moves both up and down instead of moving only down.

So the PAYM insight does not, by itself, justify rigld prices. It does offer some relief from the notion that models with price rigidity are ipso facto implausible because keeping prices flexible is cheap. This relief is only partial. The insight also justifies keeping output fixed in response to changes that make output changes profitable. So why are the near-rational firms in the world opting to keep their prices fixed while their quantities vary. Perhaps this is a coincidence. More likely, one needs nontrivial 
costs from making prices flexible.

Before closing this section is is worth speculating on the additional richness that the PAYM insight would give more traditional dynamic modeis. In such models, the effects of temporary increases in government spending depend on the marginal propensity to consume. Yet, an optimizing individual is essentially indifferent as to when he spends an additional dollar of income. This means that the marginal propensity to consume can be any finite number (positive or negative), and individuals would still only suffer second order losses from their lack of perfect optimization.

\section{A Static Model with Monopoly}

In this section I consider a simple static general equilibrium model. This model borrows heavily from Rotemberg (1982b), Mankiw (1985), Bianchard and Kiyotaki (1985) and Ball and Romer (1986b). The representative consumer at $t$ has a utllity function given by ${ }^{9}$ :

$$
\mathrm{U}_{\mathrm{t}}=\left[(1 / \mathrm{J}) \underset{\mathrm{i}=1}{\mathrm{~J}}\left(_{\mathrm{JC}} \mathrm{JC}\right)^{\theta}\right]^{\beta / \theta} / \beta-\mathrm{L}_{\mathrm{t}},
$$

where there are $\mathrm{J}$ goods, $\mathrm{C}_{\mathrm{it}}$ is the consumption of good $\mathrm{i}$ at time $\mathrm{t}$ while $L_{t}$ is labor supplied at $t$. The parameter $\beta$ must be smaller than one to guarantee concavity. Consumers maximize at $t$ the expected present discounted value of $U_{t}$ which can be written as:

$$
V_{t}=E_{t} \Sigma \quad \rho^{\tau-t_{U}}
$$

In equation (2), $\rho$ is a discount factor while $E_{t}$ takes expectations 
conditional on information known at $t$. In the simplest version of the model opportunities for intertemporal trade are limited so maximizing (2) is equivalent to maximizing (1). Throughout, I impose a cash-in-advance constraint which requires that

$\sum_{i} P_{i t} C_{i t} \leq M_{t}$

where $M_{t}$ is the level of money balances and $P_{i t}$ is the price of good $i$ at $t$. The next question is how money is acquired. The simplest approach is to assume that money is the only asset and that money at $t$ is equal to labor and nonlabor income at $\mathrm{t}^{10}$. In principle, it is possible to extend the analysis so that it applies when there are other assets as well. Suppose that there is an asset whose nominal rate of return from to $t+1$ is $i_{t}$. Then, the usual intertemporal budget constraint would require that

$$
\begin{aligned}
& \sum_{\tau \geq t} M_{\tau} / R_{\tau}=A_{t}+\sum_{\tau \geq t} \sum W_{\tau} L_{\tau} / R_{\tau} \\
& R_{\tau}=\underset{\substack{0 \leq j<\tau \\
0<}}{ }\left(1+i_{j}\right)
\end{aligned}
$$$$
\text { where } W_{t} \text { is the nominal wage at } t \text {. Obviously, when (5) is the }
$$
appropriate constraint, the path of interest rates must adjust for (3) to hold. Since (3) holds, one can obtain the demand for goods by maximizing (1) subject to (3). This gives:

$$
C_{i t}=\left(P_{i t} / P_{t}\right)^{-r}\left(M_{t} / P_{t}\right) / J
$$

where $r$ equals $1 /(1-\theta)$ and 
$P_{t}=\left[\sum_{i}\left(P_{i t}\right)^{1-r}\right]^{1 /(1-r)}$

so that $P_{t}$ is a price index for period $t$. Constant elasticity demand functions like (6), or the very slight generalization in which real money balances are raised to a power as well, are a virtual constant in this literature. If, in addition, it ls assumed that no saving takes place, one can obtain a static labor supply schedule, which is given by:

$$
L_{t}=\left(W_{t} / P_{t}\right)^{1 / 1-\beta}
$$

which means that labor supply is upwards sloping as long as the utility function is concave in consumption.

Firms are assumed to be monopolistic competitors who maximize the expected present discounted value of profits. These firms are assumed to take the wage as glven and to have access to a linear technology so that

$$
Q_{i t}=L_{i t},
$$

where $Q_{j}$ is output of good 1 at $t$ while $L_{i t}$ is labor input into good $i$ at $\mathrm{t}$.

In the absence of price rlgidities the firm's problem is thus the usual monopoly problem with constant marginal cost $\mathrm{W}_{t}$ and constant elasticity of demand. For the monopolists problem to be well defined, this elasticity $r$ must exceed one, so that $\theta$ must be between zero and one. Prices then equal $W_{\mathrm{t}} / \theta$. Under the assumption that the labor market clears, equilibrium wages can be obtained from (7) and (6). Using these wages, the optimal price from the point of the view of a single firm, $P^{*} t$ is approximately 11 : 


$$
P^{* *_{t}}=P_{t}\left(M_{t} / P_{t}\right)^{1-\beta / \theta}
$$

When all firms charge this optimal price, equllibrium aggregate output, real money balances and employment equal $\theta^{1 /(1-\beta)}$.

Under perfect competition, which obtains here if each good is supplied by two firms competing in Bertrand fashion, the real wage is one and employment is one. So, since $\theta$ is less than one and $1 /(1-\beta)$ is greater than one, output is lower under monopoly than under perfect competition. The tendency for monopoly to ralse price transiates in general equilibrium into low real wages which discourage labor supply.

\section{An Increase In the Money Supply In a Two-Period Model}

The simplest dynamic model in which the effects of increases in money in the presence of rigid prices can be studied has two periods. In the first period money is given by some initial value $M_{0}$ and is expected to remain at this level forever. Prices are therefore glven by (9) with money equal to $\mathrm{M}_{\mathrm{O}}$. In the second period, money increases unexpectediy by $\mathrm{k}$. In the absence of rigidities, prices would rise by $k q$, output and real balances would be unaffected. Suppose however that changing prices is costly. Mankiw (1985), Akeriof and Yellen (1985) and Blanchard and Kiyotaki (1986) compute the size of this cost which leaves firms indifferent between maintaining the first perlod price and raising their price.

The way this computation Is carried out in Mankiw (1985) and Blanchard and Kiyotaki (1986) is to assume that all firms hold their price fixed and to compute the gain to a single firm from optimally changing its price. Denote this gain $f(k)$ where, for small $k, f(k)$ is proportional to $k^{2}$. For costs of 
changing prices equal to $f(k)$, not changing prices is an equilibrium.

As discussed in Rotemberg and Saloner (1986) this equilibrium is not unique. This can be seen as follows. Suppose that the firm which sells good j raises its price. This will raise the demand of firms producing substitutes for good $j$. With the demand curves given by (6), the demand for all other firms increases as long as the elasticity of demand, $r$, exceeds one. This additional demand provides an additional incentive to raise prices. Thus, if costs of changing prices equal $f(k)$ and one firm raises its price, It becomes optimal for all the others to change their price. Such a collective price increase would of course also make it optimal for the original firm to raise its price. There is thus also equilibrium in which all the firms raise their price. Of course, for costs of changing prices sufficiently big (1.e. bigger than some critical level $f^{2, k}(k)$ ) a single firm would not change its price even if all other firms changed theirs. Only for costs larger than $f^{*}(k)$ is not changing prices the unique equilibrium. For costs of changing prices between $f(k)$ and $f$, $(k)$ there are two additional equilibria. In one of these, all the firms change their price. In the other, a fraction $\alpha$ between zero and one of the firms change their price. This fraction $\alpha$ is increasing in the cost of changing prices. Given that this fraction is changing its price, firms are indifferent between changing their prices or not.

Still, for some level of costs which, for $\mathrm{k}$ small, is proportional to $\mathbf{k}^{2}$, price fixity is the unique equilibrium and, given (6), output rises. At this point, it is worth raising the question of what preciseiy makes price changes costly. There are undoubtely some small administrative costs of changing prices. These are sometimes referred to as "menu" costs although more than the printing of menus must be involved since the newstand price of 
magazines is printed with the rest of the magazine,. Another possibie cost, which is stressed by Okun 12 (1981, p.141-53) and Rotemberg (1982b), is the cost of customer dissatisfaction with firms whose pricing appears erratic ${ }^{13}$.

Ideally such customer dissatisfaction would be modelled explicitly and much remains to be done on this. For the moment imagine that any change in price costs goodwill which affects future purchases. At least to some extent, the loss in goodwill by one's competitor is a gain to oneself. It is even possible that the loss in goodwill from changing one's own price is reduced if others are changing their price as well. This would exacerbate the muitiplicity of equilibria mentioned above, since it would mean equillbria in which all firms change their prices exist even when $k$ is quite small.

The lncreased output produced when money rises requires that workers work more. It is important to discuss the mechanism that brings forth this additional effort. In the simple model outlined above, $W_{t}$ is fiexible so the real wage adjusts to make workers willing to work more. For the case of static budget constraints, the required change in the real wage can be obtained from (7). In the case in which there is an intertemporal budget constraint as in (4), the required change in the real wage is generally more difficult to compute but, conceptually, no new problems emerge. With utility strictly linear in labor supply, we know that the equilibrium nominal wage discounted at the nominal interest rate is independent of time.

An alternative approach is adopted in Blanchard and Kiyotaki (1986). They postulate that workers each possess unique attributes so that they too act as monopolistic competitors when they set their wage. Then their loss in utility from keeping their wages constant and agreeing to work more in response to increases in $M$ can also be suitably bounded. Both of these 
approaches have the very un-Keyneslan implication that in recessions workers are close to indifferent between working and not working.

Suppose then that one believes that intertemporal substitution of leisure cannot explain the movements in employment ${ }^{14}$. One can then obviously not believe that the constancy of goods' prlces ls the only departure from the classical model. But, is one then requlred to believe that there are nominal wage rigidities as well? The paper by Akerlof and Yellen (1985) suggests that this is unnecessary and that it is sufficient for there to be a "real" imperfection in the labor market.

Akerlof and Yellen (1985) postulate an "efficiency" wage which employers pay to increase worker diligence. In their model, effort by workers is increasing in the wage they recelve. This implles that the optimal real wage depends only on the responsiveness of effort to the real wage 15 . It is independent of employment and can easily be above the marginal rate of substitution between consumption and lelsure. The decline in output which results from reductlons in the money supply in the presence of rigid prices then leaves the real wage unaffected, while reduclng labor demand and increasing unemployment.

\section{Are Macroeconomic Fluctuations Excessive?: Welfare Issues}

In this Section I discuss the welfare effects of changes in the money supply. Suppose, as is true in any equilibrium that all goods are supplied in equal quantities. Then using (8), one can write individual utility as:

$$
\mathrm{L}_{\mathrm{t}}^{\beta} / \beta-\mathrm{L}_{\mathrm{t}} \text {. }
$$


Since the level of output supplied by monopolistic competitors is lower than one (the competitive levei), the derivative of the representative utility (10) with respect to employment is positive at the monopoistic equilibrium. Expansions in output are good, contractions are bad. As Mankiw (1985) points out, this accords well with popular accounts of business fluctuations. Moreover, suppose that output is sometimes high and other times low. Then, since utlity is concave in consumption the existence of aggregate fluctuations itself also reduces welfare. Stabilizing output using the money supply is a good idea.

A different question is whether stabllizing output by forcing firms to always change their prices is a good idea. This question of whether there is excessive price rigidity (or excessive output variability) given the costs of changing prices is addressed in Ball and Romer $(1986 \mathrm{~b}, 1987)$. The answer is not obvious because the losses from the fluctuations in output are of second order ${ }^{16}$, the same order as the cost of changing prices.

I now present a simplified version of the arguments in Ball and Romer (1986b,1987). Consider $k q$ changes in the money supply which are equally likely to be positive or negative. If prices are unchanged, employment changes by $\mathrm{k} q$ as well so the second order effects on utility are equal to:

$$
(\beta-1) L^{\beta} k^{2} / 2
$$

Since utlity is linear in leisure, this can be interpreted as the leisure cost of the fluctuations. Now consider the costs of changing prices which lead to the fluctuations. Here, I compute the costs $f^{\prime 2}(k)$ which ensure that the unique equilibrium has constant prices. These costs are such that even if all firms but one change their prlce optimally, i.e, by $k q$, the 
remaining firm would prefer to keep its price fixed. This cost is thus equal to the cost from having output differ from the optimal output by rko at the equilibrium levels of real wages and real money balances. This cost is easily computed to be:

$(\mathrm{r}-1) \mathrm{QPk}^{2} / 2$

in nominal terms. At the equilibrium real wage this equals:

$$
(\mathrm{r}-1) \mathrm{Q}^{\beta} \mathrm{k}^{2} / 2
$$

units of leisure. Equation (12) gives the costs to a firm from changing its prices while (11) gives the costs to individuals from price rigidity. Price rigidity is thus excessive, in that individuals lose more than the costs of changing prices if

$$
\mathrm{I}(1-\beta) /[\mathrm{J}(\mathrm{r}-1)]>1
$$

where $I$ is the number of individuals. A low value of $B$ renders price rigidity excessive because utility is very concave and individuals lose much when output fluctuates. Similarly, a high value for the perceived elasticity of demand, $r$, means that firms must let output fluctuate a great deal if they alone keep their prices fixed. Such large fluctuations are costly to firms, so a high value of $\mathrm{r}$ reduces price rigidity. If $\mathrm{I}$ equals $\mathrm{J}$ and firms face an elasticity of demand of at least two the ratio in (13) is less than one. Prices move too much.

Ball and Romer $(1986 \mathrm{~b}, 1987)$ also conclude that ratios of the form of 
(13) are not unambiguously greater than one. It is worth noting that I have analyzed the equllibria with least rigidity since I have assumed that a cost of $\mathrm{f}^{\text {*k }}(\mathrm{k})$ is necessary to keep prices constant. If instead, as in Ball and Romer (1986b) a cost of only $\mathrm{f}(\mathrm{k})$ is required, excess rigidity becomes more likely. As noted in Ball and Romer (1987) the welfare properties of the model depend on the choice of equilibrium.

This dependence might be even more severe if one felt the cast of changing prices represents mainly a loss in customer goodwill. Then the loss in goodwill to any single firm could be much larger if it changes its prices alone than if all firms change theirs as well. In other words, the cost from having all firms change their prices could be much lower than the sum of individual costs of changing prices. In this case equilibria with rigid prices would tend to be more inefficlent than equilibria with more flexible prices. As we will see in the next section, once dynamics are explicitly recognized the cholce of equflibrium determines not only welfare but also the qualitative features of the model.

Before closing this section, it is worth noting that the expression (11) for the welfare cost of fluctuations is valid both under monopoly and competition. One interesting feature of (11) is that the cost of $\mathrm{k}$ o fluctuations is bigger under competition (when $\mathrm{L}$ is one) than under monopoly. Because the relevant part of the utility function has constant relative risk aversion, individuals are willing to give up a certain fraction of their consumption to eliminate $k$ f fluctuations. Such a constant fraction represents more consumption when output is high, as under competition.

\section{Dynamic Models of Costly Price Adjustment: i) Ss rules}


The two period model obviousiy fails to capture an important feature of economies with rigid prices. In the presence of costs of changing prices the price that is inherited from the past is not necessariliy the price that was optimal just before the latest change in the money supply. This has the important consequence that when prices start far out of line, even a small change in the money supply can get firms over the brink and induce them to change prices. To take this into account, a modei is needed in which the money supply evolves over time and firms adopt optimal dynamic strategies. For the case of fixed costs of changing prices, a general model of this type has yet to be developed. Moreover the multiplicity of equilibria that plagues even the simple model of section IV makes it likely that such a model will be badly behaved 17 . One case for which equilibria have been studied (in Rotemberg (1983) and Parkin (1986)) is the case of constant rate of monetary growth.

Sheshinski and Weiss (1977) consider a firm for whom the optimal price in the absence of costs of changing prices $\mathrm{P}^{2, k} \mathrm{t}$ grows at a constant rate. They prove that, in the presence of fixed costs of changing prices, the firm will follow an Ss pricing policy. Each price change leads to a price equal to $S$ times $P^{2, r}$. The price is then kept constant until it equals $s$ times $P^{3 ;}$. At this point the price Is changed again. Since $\mathrm{P}^{x^{*}} \mathrm{t}$ grows at a constant rate, the time it takes for a constant price to decrease from $S P^{*}$ to $s P^{* ;}$, 1.e. the time during which the price is fixed, is constant as well.

Now suppose that the money supply grows at the rate $g$ and that the price level also happens to grow at the rate $g$. Then a firm with a demand function given by (6) would see its desired price growing at the rate $g$. It would thus choose to keep its price constant for a perlod of length $\mathrm{T}$ and change its price by gT every time It changes its price. Rotemberg (1983) assumes 
that there are a continuum of firms with such demand functions and that they start off uniformly distributed over the time of their last price change. He shows that in this case, there is a unlque equllibrium in which the price level (defined as the unweighted geometric average of the prices of different firms) does indeed grow at the rate $\mathrm{g}$. The reason for this is that over any interval of length $\tau$, a fraction $\tau / T$ of firms change their prices by $g T$ so that prices rise on average by $\mathrm{g} \tau$. Thus aggregate output does not vary over time.

In this equilibrium the distribution of the ratio of actual prices to $p^{* k} t$ is uniform with boundaries $S$ and $s$. As Caplin and Spulber (1986) have emphasized, the distribution of real prices is time-invariant as well. This fact permits a different interpretation (which I will refer to as interpretation B) of the constancy of the rate of growth of the price level. In an interval of length $\tau$, pie rises by $\tau$. This means that a fraction $\tau \mathrm{g} /(\mathrm{S}-\mathrm{s})$ of firms find their price out of line and adjust their price by (Ss). Thus the average price rises by $\tau$ g 18

It is worth noting that if as in Sheshinski and Weiss (1977) or Rotemberg (1983) the Ss rule is due to fixed costs of changing prices, an increase in the rate of inflation increases the size of individual price changes. More generally, the only case for which it is known that a constant Ss rule is optimal is the case of a constant rate of increase of $P^{\text {ric }}$.

Nonetheless, Caplin and Spulber (1986) assume that $\mathrm{S}$ and $\mathbf{s}$ are fixed independently of the stochastic nature of the economy. One defense for this approach is that, once agaln, the costs to firms from fixing these variables is small in a wide range of circumstances. Still, it is difficult to see exactly what form of "near-rationality" leads to a constant Ss rule19. One implication of constant Ss rules is that price changes are all of equal size 
when measured in percentage terms. This obviousiy rules out the possibility that the prices of some products sometimes fall and other times rise. This is counterfactual for many products. Nonetheless Cechetti's (1986) study shows that in the US the average percent change of individual magazines prices in the more inflationary 1970's is not appreciably different from the average for the 1960's. On the other hand, In their study of the prices israeli noodles, Sheshinski, Tischler and Weiss (1981) report price increases which are on average more than twice as high in the more inflationary period 1974-1978 than in the period 1965-1973.

The implications of a constant Ss rule together with what appears like a technical assumption that $\mathrm{P}^{*}$ have a monotone continuous sample path are nothing short of startling. Suppose that firms start with their prices uniformly distributed over the intervai $\left[\mathrm{SP}^{k_{k}}, \mathrm{~s}^{*_{*}}\right]$. Assume that $\mathrm{P}^{* ; c}$ rises, over some interval $\tau$ by $v$. Then a fraction $v /(S-s)$ of firms adjust their price by $(S-s)$ so that the price level rises by $v$. This is just a rewording of the interpretation $B$ given above. It means that, if the money supply rises by $\mathrm{v}$ over an interval, there is an equilibrium in which the price level does as well even though individual prices are rigid. The requirement that sample paths be monotone and continuous is necessary to ensure that the distribution of prices remains uniform after all changes in the money supply.

What the Caplin and Spulber theory obviously misses is the effect of a monetary "shock". By a shock, I mean a very short period of time during which money goes up very fast. If it happens so fast that no prices adjust in the interim, the adjustment of prices after the monetary shock leaves a distribution of prices with an atom at $\mathrm{SP}^{{ }_{1}}$; it is no longer uniform. A different possibility is that while the money supply is temporarily growing fast some firms are adjusting their prices as well. These firms, if they are 
rationai ought to anticipate that prices will grow relatively fast in the near future. They should thus increase their own prices by more than (S-s) and thus abandon the $\mathrm{Ss}$ rule. This is likely to reintroduce nonneutrailities.

Another way of seeing how optimal price adjustment rules create nonneutralities is to consider the partial equilibrium story of Tsiddon (1987). Tsiddon assumes that the economy is initially in a steady state in which $\mathrm{P}^{2}$ is growing at the rate $\mathrm{g}$ and firms are following the optimal Ss rule. He then assumes that, without any jump in $\mathrm{P}^{* ;}$, the rate of growth of $\mathrm{P}^{2, x}$ unexpectedly shifts to a lower level $\mathrm{g}^{\prime}$. This lower rate of growth is then expected to prevail forever. Firms must therefore revise their optimai Ss rule according to the formulae in Sheshinski and Weiss. It is now optimal to have a smaller band of prices, a higher value, $s^{\prime}$, for the low relative price which triggers a price change and a lower value, $S^{\prime}$, for the price that is set when prices are changed.

The question is how the firms whose prices are between $s$ and $s^{\prime}$ or between $S$ and $S^{\prime}$ should respond. Clearly those who find themselves with too low a price, i.e those between $s^{P_{k}}$ and $s^{\prime} P^{\text {k }}$, are beyond the price that triggers a change; they should raise their price to $S^{\prime} \mathrm{P}^{*}$. Instead, those who find themseives with too high a price, 1.e. those between $S^{\prime} P^{*}$ and SP*, may choose to let their price be eroded by inflation. Even if they choose to adjust their price downward the downward adjustment $\left(S^{\prime}-S\right)$ is much smaller than the upwards adjustment $\left(S^{\prime}-s\right)$ so that the price index rises on the instant in which the rate of growth of $\mathrm{P}^{\text {tw }}$ fails. It is tempting to interpret this to mean that policles of disinflation promote upward revisions in prices which contribute to recessions. This interpretation is somewhat premature because $P *$ is not being determined in equilibrium. In particular, disinflationary episodes are likely to be accompanied by increases in the 
demand for money. Suppose the disinflation is attempted by simply reducing the rate of money growth. Then pre would jump down as soon as money growth siows down, thereby reducing the incentive for prices to rise 20 .

The great insight of Tsiddon's paper is that the optimal change of Ss rules that accompanies changes in monetary policy has, itself, aggregate consequences which are missed when the Ss rule is assumed to be constant. In spite of this, the paper by Caplin and Spulber (1986) is valuable for stressing that the pervasive rigidity of individual prices does not automatically imply that monetary injections raise output.

Another way of making this point is the following. With fixed costs of changing prices very small changes in the external environment can trigger very large price changes. This occurs because at the instant of price change the firm is almost Indifferent between malntaining its current price for a while longer or incurring the cost of price change now and moving to a quite different price. This indifference san easily be broken. This means that it Is possible to imagine distributions of prices such that a small increase in the money supply makes many firms increase their price a lot so that an increase in the money supply triggers a recession 21 . The message from this line of thinking is that the distrlbution of prices is all important when deciding whether an increase in the money supply is contractionary or expansionary 22 . This is not the sort of variable that finds a natural home in popular Keynesian discussions.

\section{ii) Staggering}

The equilibrium with constant inflation considered in Rotemberg (1982) has both a constant Ss rule and intervals of constant length between price 
changes. Indeed, Just as with constant Ss rules, keeping the interval between price changes constant is generally optimai only when poir grows at a constant rate 23 . Yet there is a literature (Blanchard $(1983,1986 a)$, Ball and Romer (1986a), Ball and Cecchetti (1986), Parkin (1986)) which assumes that prices are set for intervals of constant length. This iiterature probably spawned under the influence of the earlier literature on rigid labor markets (Fischer (1976), Taylor (1980)) in which contracts of constant length have descriptive appeal.

For prlces, the notion that the interval between price changes is constant is clearly counterfactual. There is much anecdotal evidence and some hard evidence such as Cechetti's that price changes are more frequent when inflation is high 24 . Thus Reader's Digest changed its newstand price in both January 1974 and January 1975, whlle it kept its price constant between September 1957 and January 1967.

It Is worth pointling out that the assumptlon of a constant interval between price changes makes the degree of price rigidity difficult to estimate with aggregate data. One possibillty (Taylor (1980b)) is to impose a certain length for this interval before estimation. In this case, knowledge of the discount rate used by flrms completely determines the path of prices, there Is nothing else to estimate. Alternatively, one can use the procedure of Christiano (1985) who estimates the model repeatedly, letting the period for which prices are fixed be different multiples of the sampling interval. Comparison of these different estimates is of course difficult.

If in addition to maintaining the assumption of constant intervals ano imposes the condition that the number of firms that change their price in any interval of length $\tau$ is constant, i.e. that firms are uniformly distributed over the the time since they last changed their prices, some interesting 
dynamic responses of output to money emerge (See Blanchard (1983)). In particular, under this "staggering" assumption, Blanchard shows that the length of time over which a particuiar once and for all increase in money affects output can exceed the length of time for which individuai prices are fixed.

One question that has emerged in this work is, assuming firms maintain constant the intervais for which their prices are fixed, will their price changes be staggered or will firms change their prices at the same time i.e will they be synchronized 25 . This question has been asked both of models of labor contracts (Fethke and Policano (1984), Matsukawa (1985)) and of price setters (Parkin (1986), Ball and Romer (1986a)). While the resuits differ in their specifics, there is a tendency for staggered and synchronized equilibria to coexist.

This coexistence can be seen most easily for the case of constant money growth whose staggered equllibrium is discussed in the previous section. I now consider synchronized equllibria. We already saw in Section VI that if other firms raise their prices at a point in time the demand for all other firms rises. This increase in demand, in turn, raises the incentive to raise prices. This means that if all other firms are changing their prices together very often, each individual firm will want to do so as well. At this equilibrium the only reason a firm changes its price is because others do so. The firm thus has no desire to change its price between the price changes of others. This lack of desire to deviate from the equilibrium is what brings about its existence. Moreover the logic of these synchronized equilibria is such that there are several of these equilibria. These differ by the length of time during which all prices are constant 26 . This means in particular that there is no reason for synchronized equilibria to be 
periodic .

The key difference between synchronized and staggered equilibria is that in the former both the price levei and output jump around discontinuousiy. This lacks descriptive appeal. Such jumps would presumably be reported on by newspapers. Still, in both of these equilibria, as long as the intervai between price changes is constant, monetary changes generally affect output. In the staggered setting they do so because only some firms change prices. In synchronized equilibria they do so because, most of the time, all prices are constant.

The authors mentioned above have tried to derive conditions under which either the staggered or the synchronized equilibria disappear. One possible criticism of the staggered equilibrium is that it is unstabie. Nothing brings back the uniform distribution if it is ever disturbed. Yet, there are a myriad modifications of the model which ensure stability. These inciude the presence of Idiosyncratic shocks (Ball and Romer (1986a)), small differences in the Ss policies of different firms (Caplin and Spulber (1986)), as well as the randomization which is optimal to foil specuiators (Benabou (1986a)).

There are several ways of ruling out perfectly synchronized equilibria. The first is to assume that there are firm specific shocks (Ball and Romer (1986a)). Yet, even in the presence of such shocks there can be differing degrees of bunching after a monetary shock. The second is to assume the government would rapidiy reduce the money supply if all prices were to increase together (Parkin (1986)). The third is to assume that when another firm raises its price the demand for one's own product actually falls. This is impossible with the cash-in-advance constraint used here. However, Blanchard (1987) proves it to be possible if the elasticity of a firm's 
demand with respect to real money balances exceeds that with respect to the firm's price. Finally, Ball and Cecchetti (1986) argue that firms want to learn about their optimai price from their competitors price. They may thus wait until others have changed their price. In continuous time this would lead to a classic war of attrition 27 . Moreover, unless learning about prices charged by other takes time, price changes would still occurr in spurts.

\section{iii) Quadratic Costs of Changing Prices}

The difficulties with the fixed costs of changing prices model in a dynamic setting are akin to those of investment models with fixed costs of investment. If anything they are more severe because of the induced multiplicity of equilibria. The standard solution in the investment literature is to pretend that the costs of investment are convex. The justification for this, that it is easler to absorb new capacity into the firm at a slow rate, flies in the face of the lumpiness of actuai investment projects. The reason such models survive professional scrutiny is that whatever the weakness of the assumption one can actually solve them and obtain aggregate investment equations in a form suitable for estimation.

A similar reasoning might apply to costs of changing prices. Here too one could in principle argue that the cost of increasing prices is the cost of upset customers and that customers might be more than proportionately upset with larger price changes 28 . Again one would have to confront the fact that individual price adjustment is lumpy. Here this observation is more damaging, because the main reason for taking models of costly price adjustment seriously is the fact that individual prices seem sticky.

In a series of papers (Rotemberg (1982a,1982b)) I have nonetheless 
pursued the implications of quadratic costs of changing prices. I give some further justifications for their use after I draw out their impilications.

These models start from the maximization of firm profits subject to the demand given by (6) and the technology (8). This leads to a path of prices $P^{*}$ (given by (9)) which the firm would charge in the absence of costs of changing prices. As argued above, it is then possible to take a quadratic approximation of from the firm's profits around Pix. Rotemberg (1982a) then postulates that firm 1 minimizes:

$$
E_{t} \sum_{j \geq 0} j\left[\left(p_{i t+j}-p^{* *} i t+j\right)^{2}+c\left(p_{i t+j}-p_{i t+j-1}\right)^{2}\right\}
$$

where $E_{t}$ takes expectations at $t$, lower case letters are the logarithms of the respective upper case letters and $c$ is a parameter which is high if the cost of changlng prices is high. The solution to this problem is:

$$
p_{\text {it }}=\alpha p_{j t-1}+[(1-\alpha)(\delta-1) / \delta] \underset{j \geq 0}{\sum(1 / \delta) j} p^{* x} t+j
$$

where $\alpha$ and $\delta$ are related to $\rho$ and $c$; the former is smaller than one while the latter is bigger than one. This solution has a natural interpretation. Because the costs of increasing price are convex, firms opt to change thelr prices slowly. Prices are a weighted average of past prices and Pars. Because it will aiso be costly to change prices in the future, future $\mathrm{P}^{\prime \prime} \mathrm{s}$ are taken into account as well.

Aggregation of (14) accross firms, which is trivial once symmetry is recognized, gives rise to an equation analogous to (14) in which the current price level is a welghted average of the past price level and present and future levels of the money supply. This dependence of current prices on the 
future is, of course, common to all models in which rationai firms have rigid prices.

The main advantage of this quadratic approach is that it leads to equations that can easily be estimated. Rotemberg (1982b) applies it to aggregate US data while Giovannini and Rotemberg (1986) apply it simultaneously to German prices and the dollar/DM exchange rate. The model tracks fairly well the behavior of prices and exchange rates 29 .

The obvious implication of this model is that sudden increases in the money supply translate themselves rather slowly into price increases, so they raise output. This brings back the issue of how such a model, even when oniy applied to aggregate data, can be consistent with the sharp and sporadic price increases observed in micro data. The obvlous answer to this is that models of this type capture the existence of some firms who delay their price changes relatlve to the underlying fundamentals.

One model of delay whose equilibrjum looks identical to the aggregate version of (14) is presented in Calvo (1983). He assumes that firms have an exogenously given probability $\pi$ of changing their price in any particular time period ${ }^{30}$. This probability is presumably chosen optimally as well but Calvo does not allow it to vary over time. An optimizing firm who changes Its price and minimizes (13) with c set equal to zero will thus charge a price $Z_{t}$ which is a welghted sum of current and expected future $P^{x_{i}} s^{\prime}$ :

$$
Z_{t}=(1-(1-\pi) p)\left\{\sum_{j \geq 0}\left[(1-\pi)_{p}\right]^{j} p^{\prime, k} t+j\right\}
$$

The future $\mathrm{P}^{\text {2icl}} \mathrm{s}$ are less important the higher is $\pi$ and the higher the rate at which the future is discounted. The logarithm of the price level is then a weighted average of the logarithm of the past price level (with weight 
$(1-\pi)$ ) and $z$ (with weight $\pi$ ):

$$
p_{t}=(1-\pi) p_{t-1}+\pi(1-(1-\pi) \rho)\left\{\sum_{j \geq 0}[(1-\pi) \rho]^{j} p^{2, k} t+j\right\}
$$

which Is Indistlnguishable from the aggregate version of $(14)^{31}$. Thus the estimates in Rotemberg (1982)'s favorite specification impiy that in the the postwar US about 8 percent of prices are adjusted every quarter; the mean time between price adjustments is about 3 years. Instead, the estimates of Giovannini and Rotemberg (1986) impiy that between 1974 and 1982 the average time between price adjustments in Germany was of only about 12 months.

This probabilistic interpretation of an equation such as (14) has both strengths and weaknesses. The Caivo modei has the advantage that individual price changes are large while the price level adjusts sluggishly. Yet, the observation that price changes are more common in periods of high inflation is inconsistent with a constant probability of changing prices. The model aiso fails to explain why price changes are stochastic.

A partial equilibrium reason for randomizing the timing of price changes is given in Benabou (1986a). He considers demand functions for goods that are storable. Firms for whom the date of price change is known will then be subject to speculative attacks; individual will hoard their goods just before the price rises. There is then no pure strategy equilibrium to the game between price setters with constant costs of changing prices and speculators. The solution is for the price change to occur at a random date.

A different reason for delay and possibiy even for somewhat random delay is that there are both costs to gathering information and costs of changing prices. By costs of gathering information I have in mind, as do Rotemberg and Saloner (1986), that the firm does not know its optimal price without 
spending resources. If only these costs are present, prices should change often since firms would charge their best guess of the optimal price.

Suppose however that these costs coexist with costs of changing prices. Then firms will keep prices constant for some time, occasionally investigate the optimal price and only then change prices. Suppose then that the money supply rises by a known amount. Not all firms will respond by investigating their optimal price and some firms will react only with delay. This delay would obviouly become somewhat stochastic if information of varying quality is observed randomly. It ls worth stressing, however, that at this point we lack even partial equilibrium models in which costs of gathering information and of price adjustment are important.

\section{Multiple Equillbrla}

As we have seen, small costs of changing prices generate multiple equilibria. Yet, at least in the two period model and for a specified range of monetary growth, all the equilibrla feature price rigidity, and this price rigidity is responsible for the Keyneslan outcomes. In this section I review a literature in which the multiplicity of equilibria can, by itself, be vlewed as Keynesian. The connection between multiple equilibria and Keynesian economics is clearly articulated in Bryant (1983)'s model of effort in teams and in Woodford (1986). The connection is apparent once one recognizes that the equilibria differ by the (correct) beliefs agents have about their environment. These beliefs can be thought of as animal spirits.

The great strength of these models is that they illustrate the possibility that employment can fall below full employment without any adverse shift in technology or tastes. At least some of these models find 
two other features of Keynesian thinking more difficult to accomodate. The first is that large fluctuations in output are accompanied by long periods in which individual prlces are rigid. The second is that money affects output predictably. In these models, for changes in money to have an effect they must switch the economy from one equilibrium to another. They must thus affect agents beliefs about their environment in prespecified ways. Another way of posing this problem is that one can only know how money will affect output once a partlcular equilibrium is selected. Yet the models provide little guldance for this selectlon.

Somewhat arbitrarily, I divide this llterature on multipie equilibria in three strands. The flrst strand (which Is embodied in Stiglitz $(1979,1984)$ and Woglom (1982)) is closely connected to price rigidity and to the models of Sections IV-VI. It starts from partial equilibrium models with multiple equilibria. Then, a change In the money supply can be consistent with unchanged nominal prices. The second strand considers fairly classlcal models but modifies the Institutions of prlce setting, wage setting, hirlng of labor and purchasing of commodities and thereby achieves multiple equilibria. Models of this type Include those of Diamond (1982), Weitzman (1982), Cooper and John (1985) and Roberts (1986). The third strand focuses on the overlapplng generations model. As Kehoe and Levine (1985) demonstrate this model can posess a great many equilibria. These have been glven Keynesian interpretatlons by Geanakoplos and Polemarchakis (1986) and Woodford (1986). I consider these ideas in turn.

\section{i) Partial Equilibrium Multiplicities}

Consider an oligopoly whose member-firms live forever and produce a 
homogeneous good subject to constant marginal costs. One equilibrium is the usuai Bertrand one of charging marginai cost. Yet there are also equilibria with higher prices. These occur, as in Friedman (1971) because each firm knows that any undercutting of the implicitly agreed upon price will lead to a price war in which price reverts to marginal cost. Indeed, if there are not too many firms, any price between the monopoly price and marginal cost constitutes such an equilibrium. Thus, as Stiglitz (1984), notes there exists in particular an equilibrium in which nominal prices stay constant over some period of time. This equilibrium is not particularly desirable to the ollgopolists except insofar it facilitates coordination. Rotemberg and Saloner (1986b) argue that when a collusive equilibrium of this type is maintained through price leadership (1.e. by letting one firm pick the price for all firms) then the rigidity of prices is actually useful to the oligopoly. The advantage of rigidity is that it prevents the leader from exploiting the follower by varying the price to its own advantage in response to relative shifts in demand.

Similar multiplicities arise In Stiglitz's $(1979,1985)$ model of search. He considers equilibria In which all firms charge the same price. Suppose one firm decides to charge a different price. A firm that chooses to lower its price attracts very few customers because search is costly. (Indeed it attracts only those people with very low search costs who are willing to search repeatedly in order to find the one cheap store). If the firm chooses instead to raise its price it will lose many more customers since they are all sure that they can obtain a lower price by going to one additional store. Thus the demand curve facing an individual firms has a kink at the price charged by all the other firms. This tends to make this price optimal. Hence there are multiple equilibria and it is possible (and perhaps even 
natural) to keep nominal prices unchanged even when the money suppiy rises 32 .

It is worth briefly drawing the contrast between this search story and costs of changing prices, particularly when these are viewed as the cost of upset customers 33 . The two are obviously reiated since the search model implies that it is costly to charge a price different from that of other firms. In the equillbrla In which others keep thelr prlces constant, this is the same as making prlces costiy to change. The key difference between the two modeis is that In the search modei it is worth matching other firms' prices even if these are extremely volatlle. Instead, the models with costs of changing prices assume that in an envlronment with very volatile prices, a single firm would benefit, 1.e. it would please its customers, if it stabilizes its own.

Two observations deserve to be made about the muitiplicities in these models. The first is that these models are as consistent with excessively rigid as with excesslvely volatile prices. In these modeis, if people believe prices will change, such a change will take place even if nothing fundamental changes. The second is that these stories rely critically on competition among firms to generate the muitlpllcities whlch are associated with price rigidity. Thus they are hard to reconcile with the evidence that monopolies keep their prices more rigid than oligopolies .

\section{ii) Multiplicities due to non-Wairasian Institutions}

In this section, I survey models which abandon the Walrasian auctioneer in both goods and labor markets. In these models the institutional framework as well as the timing of production, pricing and exchange are modelled explicitly. Diamond (1982) presents a search model in which opportunities to 
produce arrive randomly. These opportunities differ in the amount of effort needed to obtain one unit of output. Having produced, individuals must then search for a trading partner,i.e. another person who has also produced. Oniy when they trade the fruits of their production with one another can they consume. In this model there are different equilibria corresponding to different effort levels individuais are willing to incur. If others are willing to incur much effort, there are many trading opportunities (search for trading partners will be short) and expending much effort becomes worthwhile. One interpretation for the equilibria with low levels of output is that individuals work little because, even though measured reai wages are high, individuals fear that they will find it difficult to purchase useful goods and services. This lacks descriptive power for Western countries. Another interpretation is that firms are not employing workers because they fear it will be difficult to sell the output. Under this interpretation the lack of a mechanism whereby the unemployed workers might be able to bid down wages is a drawback.

Such a mechanism is considered in the related model of Roberts (1986). This model deviates less from the Arrow-Debreu framework in that transactions are not time consuming. It differs from that framework only in the sequence of pricing and purchasing decisions. Initially, firms announce prices and wages. Workers then offer their labor. Next, firms decide who to hire and, finally, output is sold 34 . Even when he restricts himself to equilibria in which prices and wages equal their Walrasian levels, output can be anywhere between zero and the Walrasian levei. What is most remarkable about this model is that equilibria with low output have true involuntary unemployment; workers who do not work envy those who do. These equilibria can be understood as follows. As in the second interpretation of the Diamond model, 
If other firms hire few workers, few individuals will be able to afford one's own product and therefore one's demand will be low. The natural response to such low expected demand is to hire few workers oneseif.

The key question in the model is why, if there are unemployed workers, there is no pressure for wages and prices to fall. After all, a firm who lowers its price will attract a great many customers, while one who lowers its wage will still be offering appealing positions to the otherwise unemployed. This rather old question is given a theoretically very ingenious answer by Roberts. A firm who contemplates deviating by lowering its price and wage is "threatened" with a drastic change in the equilibrium if it does so.

As I mentioned, in Roberts' model there is also an equilibrium with full employment. Moreover, slnce several firms produce any given good with a constant returns to scale technology, the full employment equilibrium is feasible even leaving out one of the firms. Thus Roberts (1986) assumes that if any firm lowers its wage then the equllibrium immediately shifts to the one with full employment where this particular firm is inactive. This leaves firms indifferent between lowering their wage (and thereby eliminationg all unemployment) and keeping the same prices and wages as all the other firms.

Several features of this construction deserve to be noted. First, to support the Walrasian equilibrium in a non-Walrasian model it is obviously necessary that, if a firm producing good $j$ lowers its wages below the Walrasian level, those employed by the firm be employable (at Walrasian wages) in another firm producing good $j$. Roberts, however, requires one order of magnitude more information and coordination. When a firm producing j lowers its wage firms producing goods other than $j$ must react dramatically as well. Second, the unemployment equllibria are not robust to the 
introduction of a single civic-minded firm 35 . Such a firm would prefer to eliminate unemployment if it could do so without affecting profits. In the model, this can be achieved by lowering wages and prices. These criticisms are a little off the mark, there may be other ways of supporting equilibria with low output. The model should be seen as an important warning. Once the Wairasian auctioneer is abandoned care must be taken to ensure that equilibria are unique if one seeks to perform standard comparative statics. This warning seems particularly pertinent for the models surveyed in Section IV which lack auctloneers in both goods and labor markets ${ }^{36}$.

\section{1ii Multiplicities in the Overlapping Generation Model}

The standard overlapping generations models differs considerably from the other models considered in this survey. In particular, prices are set by a Walrasian auctioneer and dynamics are of paramount importance. Still, as Kehoe and Levine (1985) have shown, if there are several goods (or if agents live for more than two periods), the model can have continua of perfect foresight equilibrla all of which converge to a steady state. This multiplicity can be thought of as follows. In each period, there is a Walrasian auctioneer who clears current markets for goods and labor. If agents have different expectations about prices tomorrow, the prices that clear markets today will differ as well. There are multiple equilibria because different prices today are supported by different (correct) beliefs about prices in the future. It is thus natural to index these equilibria by the beliefs about the future that they require.

Geanakoplos and Polemarchakis (1986) consider a model whose multiplicities can be indexed by two numbers. They associate one number with 
expected future output and the other with the current nominal wage. Both these numbers are picked outside the model. If an increase in the money supply leaves these two variables unaffected, it has the usual Keynesian effects. One great advantage of thelr model ls that it is amenable to analysis using the standard IS-LM graphlcal apparatus. Note that in this model, prices are not rigid per se. Nominal wages stay constant when the money supply changes because expectations of future variables, including future wages, have changed in just the right way. For this story of price rigidity to be convincing, an intuitive justification for this response of expectations about the future will have to be provided.

\section{Conclusions}

In these conclusions, I glve my own views about the strengths and weaknesses of the recent crop of Keynesian microfoundations. I must start by noting that I view the existence of multiple equilibria as a weakness in any economic model. First, If many thlngs can happen the models are much more difficult to reject. Indeed whether It ls even possible to reject models like those in Sectlon VII is an open question. Secondly, and perhaps more importantly, when there are multiple equilibrla it is impossible to know how the economy will react to any particular government policy.

Therefore I view the models surveyed in the last section as incomplete. All three types of models suggest literally that any level of output is an equilibrium. My hope is that ways will be found to rule out all but a set of locally unique equilibrla in these models. For instance, in the case of supergames the equilibrlum with the highest profits for the oligopoly, at least when the flrms are symmetrlc, appears natural. If this locally unique 
set of equilibria turns out to involve expansions in GNP in response to increases in the money supply, the models would obviously provide more solid Keynesian microfoundations.

Unfortunately this criticism also applies at least to some extent to models in which there are costs of changing prices. This is true even though the obvious purpose of these models is to provide unique Keynesian equilibria. The reason, as I showed, is that any increase in prices by other firms creates an additional incentive to raise one's own price. There thus tend to be equilibria with varying degrees of price rigidity. Moreover these equilibria can be qualitatively quite different; in some the price level evolves smoothly, in others it is subject to large jumps. Perhaps most dramatically, whenever prices are different from optimal prices there exists the possibility that prices will change simply because they are expected to change. Here too it would be good to know how to select equilibria.

Yet, there is perhaps another way of thinking of these models. Suppose the evolution of money can be characterized by a stationary stochastic process. Then an equilibrium can be thought of as a stochastic process for prices which dictates the prices to every concelvable eventuality. As mentioned above, there are many such equilibria. In spite of this multiplicity, the model would still provide rather strong Keynesian microfoundations if every such equilibrium exhibited positive correlation between monetary surprises and output. This would still leave open the question of how to empirically validate the model. Tests would have to be designed that examine only the features which are common accros equllibria.

Even this is not enough. There must also be some equilibrium which is consistent with both the aggregate price data (prices respond slowly to money) and the individual price data (inflation makes price changes larger 
and more frequent). As is clear from the discussion in Section VII, no existing model satisfies these dual requirements. While some of the existing models can account for some features of the aggregate data, they do not explain the individual data.

The task proposed in the previous paragraphs is daunting. Yet, there are two grounds for feeling it will ultimately be completed. The first is the pervasive microeconomic evidence that firms perceive price changes as costly. In particular, the fact uncovered by Stigler that prices of monopolies are more rigid than prices of duopolles is, as Rotemberg and Saloner (1986) show, an almost natural consequence of fixed costs of changlng prices. This is most easily seen when a decrease in cost occurs. Then, one reason for a single firm in an oligopoly to lower its prices is its desire to undercut its competltors and take customers from them. This is an incentive to lower prices which monopolists obviously don't perceive. So the equilibrium with rigid prices is more easily disturbed in an oligopoly. Oligopolists are more likely to change prices when costs change or, as Rotemberg and Saloner (1986) show, even when there is aggregate inflation.

The second reason for optimism is that the papers I have surveyed in sections V-VII, while not the final word, have clarified greatly which features of price rlgidity lead to Keyneslan effects and which do not. Thus we have learned from Caplln and Spulber (1986) and Tsiddon (1986) that it is the fact that firms will optimally change both the lowest relative price they are willing to tolerate and the relative price they set when they change their price which is responsible for mone', y nonneutralities. Similarly the staggering literature teaches us one important form the muitiplicitins of the static model take when firms are embedded in a dynamic context. It also shows how these multiplicities can be consistent with having each equilibrium 
be subject to monetary noneutralities. Finally the models of Rotemberg and Calvo show how aggregate dynamics may be easier to understand and estimate when individual decisions involve some stochastic elements. 


\section{FOOTNOTES}

1 Note that I am Ignoring the effect from increases in money balances on real activity which operate through the effect of open-market operations on the distribution of money balances accross families. See Grossman and Weiss (1983), Rotemberg (1984), Fusselman and Grossman (1986) and Romer (1986) for an analysis of these effects. Here I am implicitely treating changes in money as being proportionately equal accross famllies.

2 In the Treatise on Money Keynes says:"neither economists nor bankers have been quite clear in their minds as to the casual process through which a reduction in the quantity of money leads eventually to a new equilibrium with a lower level of money-earnings and of prices" (v. 1 p. 272, emphasis added). In the General Theory p.173 this mechanism is outlined in recognizable IS-LM terms.

3 Models of this type include those of Hart (1982), Startz $(1984,1986)$ and Mankiw (1986b).

4 This emphasis itself is not altogether novel. See Means (1935), McCallum (1980), Gordon (1981) and Okun (1981).

5 This list also gives the orderlng of the variables. Only lagged variables (four lags of each variable) enter in the equation that explains current military spending and so on.

6 See Geary and Kennan (1982).

7 Suppose Robinson Crusoe's utllity function is Cobb-Douglas over consumption and lelsure with an exponent on consumption equal to $1 / 3$.

Suppose that there are 24 hours of leisure per period and that there is a linear technology that converts hours of work into consumption. Then optimal labor supply is 8 hours. Raising labor supply by 108 lowers utility by .28.

8 Near rationality can justlfy also the polar opposite of excessive movements in output. It is for instance near rational for Robinson Crusoe to maintain constant his leisure in response to small variation in his productivity.

9 The model can thus be interpreted as either having a single consumer or all variables can be interpreted on a per capita basis.

10 This approach creates some delicate issues of timing. First the money supply is announced. Then, nominal wages are set to clear the labor market. This is followed by an opportunity for firms to set (or change) their prices. Banks then must extend credit to workers and equity-holders. This credit is in the form of money which is spent on goods. At the end of the period the firms then given the money to the banks ln the name of the workers and capitalists thereby canceling their debts.

11 This approximation is exact whenever, as in the flexible price 
equilibrium, firms all charge the same price.

12 Okun's anaiysis differs from that in the text because he feel that customers are upset oniy if firms change prices in response to demand changes while they accept changes based on movements in costs.

13 Whichever of these costs is deemed important, it is obviously minimized when prices are quoted in the unit of the means of payment. McCallum (1986) also argues that fixing prices in different units (i.e. in terms of an index of prlces) provides only small benefits.

14 See Mankiw, Rotemberg and Summers (1985), Eichenbaum, Hansen and Singleton (1985) for aggregate evidence on this sort of intertemporai substitution.

15 For a general discussion on the strengths and weaknesses of efficiency wage models see Katz (1986) and Stiglitz (1986).

16 To first order, the gain from an expansion equals the size of the expansion times the marginal utility of employment. Thus if contractions are as likely as expansions of the same size the first order effects of both cancel.

17 Indeed, Gertner (1986) shows that in a simple dynamic model with fixed costs of changing prices the multiplicity of equillbria makes it possible to support the collusive nutcome in an oligopoly. Deviations from this equilibrium are deterred with the credible the threat of moving to another equilibrium.

18 This is the same interpretation as above once it is recognized that, with constant Inflation (S-s) equals $\mathrm{gT}$.

19 One possibility is that, where it for costs of changing prices alone, firms would keep their prices fixed for even longer intervals and thus have even bigger price changes whenever they choose to change their price. The firms might then be forced into a constant $S, s$ rule If customers found nominal increases of more than $(\mathrm{S}-\mathrm{s})$ percent intolerable.

20 See Dornbusch and Fischer (1986) for evidence that the major episodes of disinflation are accompanied by great surges in money demand. That these increases in money demand are generally not fully accomodated by expanded money supply can be seen from the high interest rates which tend to accompany disinflations.

21 It is actually quite easy to construct fully worked out examples in which monetary expansions reduce output in these models. Suppose the economy starts in a boom. Now consider a sudden increase in the money supply after which money will be constant. This tends to make all firms adjust their prlce to the new long run optimal level. This brings output back to its normal level.

22 This result is reminiscent of the importance of the cross sectional distribution of money balances in general equilibrium models in which money 
is held because there is a fixed costs of converting bonds into money. See Grossman and Weiss (1983), Rotemberg (1984), Fusselman and Grossman (1986), Romer (1986).

23 It is possible to have i.1.d. demand shocks as well (as in Parkin (1986)) only if price must be set before demand is observed. Conversely if there is any stochastlc element to demand that is observed before prices are set it will be generally optimal, at least for some realizations of demand, to incurr the cost and change price.

24 Additional evidence against the hypothesis that the interval between price changes is constant is provided by Lleberman and Zilberfarb (1985) and Sheshisnki, Tischler and Weiss (1985).

25 This synchronization is called bunching by Parkin (1986).

26 See Ball and Romer (1987).

27 See Fudenberg and Tirole (1986) and the refernces cited therein.

28 As Cecchettl points out this may be responsible for the fact that the size of magazlne price changes does not rise appreclably in the 1970's.

29 It Is statistically rejected when required to fit all aggregate output dynamics; the demand equation glven by aggregating (6) is too simple.

30 Calvo's model is in continuous time but the basic structure is the same as the discrete time model presented below.

31 This argument may imply that other solutions to quadratic optimization problems (such as those for investment, labor demand or inventory accumulation) are also intimately linked to the solution of problems with random delays.

32 The macroeconomic multiplicitles that result from the story in Stiglitz (1979) can be found in Woglom (1982).

33 The model of Benabou (1986b) has both search costs and costs of changing prices although here these are best interpreted as administatlve costs. With both these costs and positive inflation he shows that there exists an equilibrium in which prices are dispersed even when the corresponding static model has as its unique equilibrium all firms charging the monopoly price.

34 This describes timing in the second of Robert's models. In his first model workers must simultaneously announce their offers of labor and puchases of goods. As a result indlviduals refuse to purchase from low-priced firms if they fear that these will be unable to attract the necessary workers.

35 Joe Kennedy's Cltizens Energy Corporation is ruled out.

36 The unlqueness of the model fleshed out in Section IV is due to the presence of a Walrasian auctloneer who clears the labor market. 


\section{REFERENCES}

Akerlof, G. and J. Yellen. 1985. A Near-Rational Model of the Business Cycle with Wage and Price Inertia. Quarterly Journal of Economics. 100:823-38

Ball, L. and D. Romer. 1986a. The Equillbrium and Optimal Timing of Price Changes. (mimeo)

---. 1986b. Are Prices Too Sticky? (mimeo)

----, 1987. Sticky Prices as Coordination Failure.

Ball, L. and S. Cecchetti. 1986. Imperfect Information and Staggered Price Setting. (mimeo)

Barro, R.J. 1972. A Theory of Monopollstic Price Adjustment. Review of Economic Studies. 39:17-26.

---- 1977. Long-Term Contracting, Sticky Prices, and Monetary Policy. Journal of Monetary Economics. 3:305-16

Benabou, R. 1986a. Optimal Price Dynamics and Speculation with a Storable Good. Chapter 1: MIT Ph.D. thesis.

Ph.D. thesis.

Blanchard, O.J. 1983. Price Asynchronization and Price Level Inertia.

Dornbusch and Simonsen, eds., Inflation, Debt and Indexation. MIT Press:3-24. $101: 543-565$.

---. 1986a. The Wage Price Spiral. Quarterly Journal of Economics.

Employment in the US. (mimeo)

-..- 1987. Why Does Money Affect Output? A Survey. Forthcoming In B. Friedman and F.Hahn eds. Handbook of Monetary Economics

Blanchard, O. and N. Kiyotaki. 1986. Monopolistic Competition and the Effects of Aggregate Demand. (mimeo)

Bryant, J. 1983. A Simple Rational Expectation Keynes-Type Model. Quarterly Journal of Economics. 98:525-8.

Calvo, G.A. 1983. Staggered Prices in a Utility-Maximizing Framework. Journal of Monetary Economics. 12:383-98

Caplin A.S. and D.F. Spulber. 1986. Menu Costs and the Neutrality of Money. Quarterly Journal of Economics. forthcoming

-... 1985. Menu Costs, Inflation and Endogenous Relative Price 
Variability. Quarterly Journal of Economics. forthcoming

Cariton, D. 1986. The Rigidity of Prices. American Economic Review. 76$4: 637-658$.

Cecchetti, S. 1986. The Frequency of Price Adjustment: A Study of the Newsstand Prices of Magazines, 1953 to 1979. Journal of Econometrics. 31:25574

Christiano, L.J. 1985. A Method for Estimating the Timing Interval in a Linear Econometric Model, with an Application to Taylor's Model of Staggered Contracts. Journal of Economic Dynamics and Control. 363-404.

Cooper, R. and A. John. 1985. Coordination Failures in Keynesian Models. Cowles Foundation, 745, mimeo.

Diamond, P. 1982. Aggregate Demand Management in Search Equilibrium. Journal of Political Economy. 90:881-894.

Dornbusch, R. and S. Fischer. 1986. Stopping Hyperinflations Past and Present. Weltwirtschaftsllches Archlv. 122:1-47

Eichenbaum, M.S., L.P. Hansen and K.J. Singleton. 1985. A Time Series Analysis of Representative Agent Models of Consumption and Leisure under Uncertainty. mimeo.

-..- and K. Singleton. 1986. Do Equilibrium Real Business Cycle Theories Explain Post War Business Cycles? S. Fischer, ed., NBER Macroeconomics Annual: 1. MIT Press.

Fethke, G. and A. Policano. 1984. Wage Contingencies, the Pattern of Negotiation and Aggregate Implications of Alternative Contract Structures. Journal of Monetary Economics. XIV:151-171.

Fischer, S. 1977a. Long Term Contracts, Rational Expectations, and the Optimal Money Suppy Rule. Journal of Political Economy. 85: 163-190.

Friedman, J.W. 1971. A Non-Cooperative Equilibrium for Supergames. Review of Economic Studles. 28:1-12

Fudenberg, D and J. Tirole. 1986. A Theory of Exit in Duopoly. Econometrica. 54:943-60

Fusselman, J. and S. Grossman. 1986. Monetary Dynamics with Fixed Transactions Costs. mimeo.

Geanakoplos, J.D. and H.M. Polemarchakis. 1986. Walrasian Indeterminacy and Keynesian Macroeconomics. Review of Economic Studies. 53:755-80.

Geary, P. and J. Kennan. 1982. The Employment Real Wage Relationship: An International Study. Journal of Political Economy. 90:

Gertner, Robert. 1985. Dynamic Duopoly with Price Inertia. Mimeo 
Gordon, R.J. 1981, Output Fluctuations and Gradual Price Adjustment. Journal of Economic Literature, 19:493-530

-.--, 1983. A Century of Evidence on Wage and Price Stickiness in the United States, the United Kingdom, and Japan. in J. Tobin ed. Macroeconomics, Prices and Quantities. The Brookings Instltution. Washington.

Grossman, S. and L. Welss. 1983. A Trnsactions Based Model of the Monetary Transmission Mechanism. American Economic Review. 73:871-80

Hall, R.E. 1980. Employment Fluctuatlons and Wage Rigidlty. Brookings Papers on Economic Activity. 1:91-124

Hart, O. 1982. A Model of Imperfect Competition with Keyneslan Features. Quarterly Journal of Economics. 97-1:109-138.

Katz, L. 1986. Efficiency Wage Theories: A Partial Evaluation. NBER Macroeconomics Annual. 1:235-290.

Kehoe T.J. and D.K. Levine. 1985. Comparative Statics and Perfect Foresight in Infinite Horizon Models. Econometrica. 53:433-53

Keynes, John M. A Treatise on Money, Macmillan, London, 1930 (1965)

.1935. The General Theory of Employment Interest and Money,

King, R. and C. Plosser. 1984. Money, Credit and Prices in a Real Business Cycle. Amerlcan Economlc Revlew. 74-3:363-380.

Lieberman Y. and B. Zilberfarb. 1985. Price Adjustment Strategy under Conditions of High Inflation: An Empirical Examination. Journal of Economics and Buslness. 37:253-65

Lucas, R.E. 1973. Some International Evidence on Output-Inflation Tradeoffs. American Economic Review. 63:326-334.

Mankiw, N.G. 1985. Small Menu Costs and Large Business Cycles: A Macroeconomlc Model of Monopoly. Quarterly Journal of Economics. 100-2:529539.

- 1986a. Comment. Macroeconomics Annual. 139-45

-.-. 1986b. Imperfect Competition and the Keynesian Cross. mimeo.

-..-, J.J. Rotemberg and L.H. Summers. 1985. Intertemporal Substitution in Macroeconomics. Quarterly Journal of Economics. 100:225-52

Matsukawa, S. 1985. Aggregate Implications of Taylor Contracts: A Game Theoretic Approach. (mimeo)

McCallum, Bennett T. 1980, Rational Expectations and Macroeconomic Stabilization Policy. Journal of Money Credit and Bankng, 12:716-46

-..- 1986. On "Real" and "Stjcky-Price" Theories of the Business 
Cycle. Journal of Money Credit and Banklng, 18:397-414

Means. G.C. 1935. Industrial Prices and their Relative Inflexibillty. US Senate Document 13, 74th Congress, 1st Session, Washington.

Okun A. 1981. Prices and Quantitles: A Macroeconomic Analysis. The Brookings Institution, Washington

Parkln, M. 1986. The Output Inflation Trade-off When Prices Are Costly to Change. Journal of Political Economy. 94:200-24

Poterba, J., J.J. Rotemberg and L. Summers. 1986. A Tax Based Test of Nominal Rigidities. American Economlc Revlew. 76-4: 659-675.

Romer, D. 1985. A Simple General Equillbrium Version of the Baumol-Tobln Model. mimeo.

Rotemberg, J.J. 1982a. Monopolistlc Price Adjustment and Aggregate Output. Revlew of Economic Studies. 49:517-31.

-.--. 1982b. Sticky Prlces In the Unlted States. Journal of Political Economy. 90:1187-211

--.- 1983. Aggregate Consequences of Flxed Costs of Changing Prices. Amerlcan Economlc Revlew. 73:433-6

-.-- 1984. A Monetary Equillbrium Model with Transactions Costs. Journal of Polltical Economy. 92:40-58

Rotemberg, J. and A. Glovannlnl. 1986. Exchange Rates with Stlcky Prices: The Deutsche Mark, 1974-1982. (mimeo)

Rotemberg, J. and G. Saloner. 1986a. Price Leadership. Economics Working Paper, MIT.

Paper 1943.

Sheshinskl, E. and Y. Weiss. 1977. Inflation and Costs of Price Adjustment. Review of Economic Studies. 44:287-304.

Sheshinski, E., A. Tishler and Y. Weiss. 1981. Inflation, Costs of Adjustment and the Amplitude of Real Price Changes" In J. Flanders and A. Razin eds. Developments in an Inflatlonary World, Academic Press, New York.

Sims, C. 1972. Money, Income and Causality. American Economic Review. $62: 540-542$.

Startz, R. 1984. Prelude to Macroeconomics. American Economic Review. 74:881-92

-... 1986. Monopolistlc Competition as a Foundation for Keynesian Macroeconomic Models. (mimeo) 
Stigler, G.J. 1947. The Kinky Oligopoly Demand Curve and Rigid Prices. Journal of Polltical Economy. 55:432-49

-... and J. Kindahl. 1970. The Behavior of Industrial Prices. Columbia Unlversity Press. NY

Stiglitz J. 1979. Equilibrium in Product Markets with Imperfect Information. American Economic Review. 69:339-45

-... 1984. Price Rigidities and Market Structure. American Economic Review. 74-2:350-355.

.... 1985. Competitivity and the Number of Firms in a Market: Are Duopolies more Competitive than Atomistic Markets ? mimeo.

-..-. 1986. Theories of Wage Rigidity. in Butkiewicz et al eds. Keynes' Economic Legacy: Contemporary Economic Theories. Praeger, NY

Taylor, J.B. 1980a. Aggregate Dynamics and Staggered Contracts. Journal of Political Economy. 88:1-24.

...- 1980b. Output and Price Stabllity: An International Comparison. Journal of Economic Dynamics and Control. 2:109-32

Tsiddon, D. On the Stubborness of Sticky Prices, 1986. Working paper.

Weitzman, M.L. 1982. Increasing Returns and the Foundations of Unemployment Theory. Economic Journal. 92:787-804

Woglom, G. 1982. Underemployment Equilibrium with Rational Expectations. Quarterly Journal of Economics.89-107 mimeo

Woodford, M. 1986. Expectations, Finance and Aggregate Instability. 
Table 1

Responses to a Monetary Innovation in a

Vector Autoregression

a) System in Levels

Quarter $\begin{gathered}\text { Response } \\ \text { of }\end{gathered}$ Money GNP Deflator

$\begin{array}{llll}0 & 1 & 0.46 & 0.19 \\ 1 & 1.22 & 0.57 & 0.31 \\ 2 & 1.25 & 1.03 & 0.47 \\ 3 & 0.98 & 0.81 & 0.66 \\ 4 & 0.66 & 0.39 & 1.08\end{array}$

b) System in First Differences

Quarter $\begin{gathered}\text { Response } \\ \text { of }\end{gathered} \quad$ Money GNP Deflator

$\begin{array}{llll}0 & 1.00 & 0.48 & 0.21 \\ 1 & 1.31 & 0.63 & 0.38 \\ 2 & 1.41 & 1.13 & 0.60 \\ 3 & 1.26 & 1.00 & 0.86 \\ 4 & 0.90 & 0.74 & 1.09\end{array}$




$$
1813.880
$$







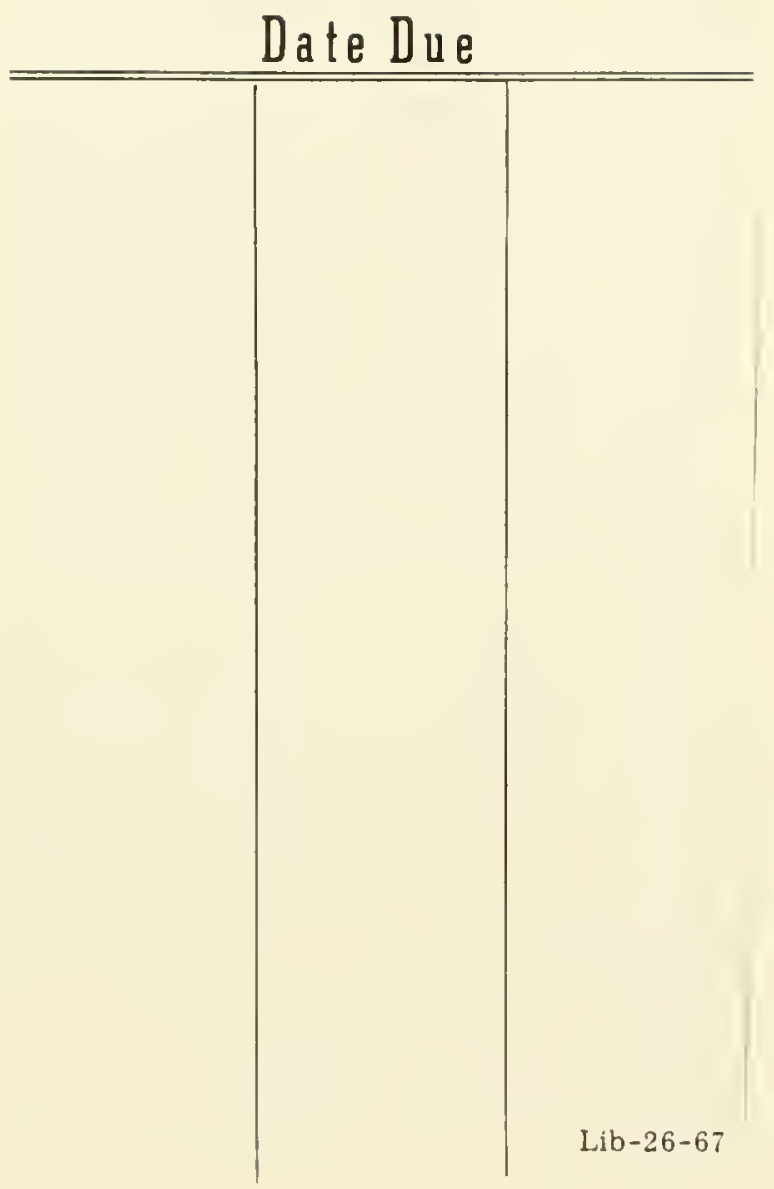




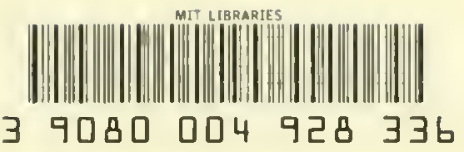


